\title{
URBAN HOUSING DEVELOPMENT: TOWN PLANNING ISSUES
}

\author{
Ibrahim Mohd@ Ahmad ${ }^{1}$, Ezrin Arbin \& Ahmad Ramly \\ Faculty of Built Environment \\ UNIVERSITY OF MALAYA
}

\begin{abstract}
Town planning is seen to have imposed some degree of constraint on housing development and is discussed in a voluminous literature on the relationship between the planning system and housing land supply. The constraints are believed to have partly contributed to the increase in housing production costs leading to a mismatch between housing supply and demand. Since the government has entrusted the private sector to play an important and bigger role to meet housing needs, local planning authorities and planners should be more cautious in fulfilling their role in housing development. This paper attempts to raise some pivotal aspects of town planning that relate to the problems associated with housing land development in West Malaysia. The primary data was gathered through personal interviews with selected housing developers and analyzed using the factor analysis tool in SPSS. The result of the analysis shows that several aspects of town planning are strongly correlated with development plans and development control factors particularly on land identified for housing, layout plan approval and complying with planning standards.
\end{abstract}

Keywords: Town Planning Issues, Housing Developers, Development

\section{INTRODUCTION}

Owning a house is a gift to a family (Murie, 1976). To own a house, a family can either buy a house on a piece of land or in a high rise building or build a new house on their land. In urban areas, a family has less opportunity to build a home of their own except in traditional villages, self-help housing schemes such as in Salak Selatan, Kuala Lumpur and in squatter areas. However, squatter houses are considered illegal structures sitting on illegal land. Therefore, most inhabitants have more opportunities to buy houses in housing schemes where houses are built in various types such as flat, terrace, semi-detached and detached along with planning and building approval. All houses are made of concrete and roof tiles - the so called conventional type of housing.

${ }^{1} \mathrm{He}$ can be contacted at ibrahim@mail.alambina.um.edu.my . 
Unfortunately, not all urban inhabitants (families, couples, bachelors) are able to live in such housing schemes because houses in the market are sold at the prices beyond their affordability. In big cities like Kuala Lumpur, about $30 \%$ of families living in squatter areas manifest that they were unable to buy houses in the market (CHKL, 2000). In this respect, many studies were carried out especially in the field of low cost and affordable housing. Based on their reports, inadvertently, the town planning was seen to be one of the factors that affect house prices (Agus, 1992; Chan, 1997; Marbeck, 1997, Ghani and Lee, 1997; Khairuddin, 2002). This is because in the housing production process, various stages are involved that, among others, include: schematic and layout submission; planning submission; and building submission. Thus, delays in the approval process, conditions specified in the approval and amendments required to the plan would have resulted in extra production costs compared to the initial proposal. Subsequently, the house prices would be set above the production costs.

From the economic point of view, the price of a property is determined by the property market - namely the supply and demand. The supply of new houses depends upon factors of production costs namely: land prices, building materials, labor wages, and management costs (Ghani and Lee, 1997). When the production cost is higher than the price, developers do not go ahead with the housing project, resulting less housing supply. The house prices of the existing housing stock will increase due to high demand (Harvey, 1992). The high demand for housing was seen during the economic booms when households had more disposable incomes. Conversely, the low housing demand was experienced during the economic recessions. The indication of the high demand for housing based on the economic cycle, boom and burst, can not be easily responded by housing developers because various factors affected their production along the development process (Simon and Henneberry, 2002). Among the factors was urban planning control because all development must obtain planning permission.

The planning permission for all development can only be obtained from the local planning authorities. These authorities, in West Malaysia, are empowered by the Town and Country Planning Act 1976 (Act 172) and its amendments, except for Federal Territory Kuala Lumpur, of which the planning law is called the Federal Territory (Planning) Act 1982. Thus, the planning authorities, as provided by law, are trying to implement the related and relevant government policies as well as to achieve the common planning objectives namely to provide the right site, at the right time, in the right place, for the right people which ultimately creates conducive urban environment for inhabitants and economic activities (Ratcliffe, 1981). 
Hence, all development of either merely one unit or more houses must obtain planning permissions and building approvals. The latter is actually not a function under the Town and Country Planning Act but it is under the Street, Drainage and Building Act 1974. In the process of getting these approvals there have been many issues raised up by those related studies. Among the most popular issues highlighted are the delays in obtaining the approvals. The claims, however, do not identify which planning factors cause problems and additional costs to the housing development or whether town planning causes are more problematic than the other factors, or 'planning problems' as mentioned may not refer to the actual planning activities but the building control under the planning department.

Therefore, the objectives of this paper are: first, to identify the subject of town planning control that cause difficulties to housing developers in developing housing estates from the view points of housing developers in West Malaysia; and the second, to identify the dimension of the interrelated constraint factors concerning the housing development associated with urban planning control in West Malaysia. In order to achieve these objectives, the discussion starts with the planning for housing as the background for housing provision and delivery system and followed by literature on planning constraints in developing housing and end with findings and conclusion.

\section{PLANNING FOR HOUSING}

There have been various efforts by the government to provide adequate housing or to meeting housing needs especially in major towns in Malaysia. In the early independent period, the government had highlighted the importance of providing public housing for the urban poor. Then, this effort was followed by the allocation of government funds to local authorities and financial institutions. The rate of interests and loan repayment periods were also touched. The high urban growth rates between 1960 s and 1970 s were seen as one of factors undermining the effort to provide adequate housing (Ozay, M 1988, Johari, M.Y 1991). The proliferation of squatter housing in major urban areas stimulated the government to solve the problems. In the Third Malaysia Plan (1976-1980), the government set the significant objective in the housing sector. The main objective was to have all Malaysians living in decent homes. The general definition of a decent home was referred to a house that provides safety, healthy, security, has adequate basic facility and has high accessibility to community facilities and amenities. In order to achieve these objectives, the government also realized that a home to a family must be within the affordable 
prices. Accordingly, the government outlined many measures to be implemented within the period of all the following Five year Malaysia plans. Among the measures were: the arrangement of finance for the owner occupier, identifying key players and encouraging private sector involvement. Looking at these measures, it seems that the government is more concerned with the conventional type of houses when it formulated housing objectives. In the Seventh Malaysia Plan (1995-2000), the targeted houses to be built were 800,000 units of which 71 percent will be built by the private sector. In the Eight Malaysia Plan (2001-2005), the objective of housing development program was "to increase accessibility to adequate, affordable and quality houses for all income groups. Priority will continue to be given to the development of low- and low medium-cost houses". To meet this objective, it was expected that the public and private sectors will intensify their efforts to meet the increasing demand. However, at the end of the plan period, the Bank Negara Annual Report 2005 highlighted that the number of houses built exceeded the target in the medium and high cost category. Until the end of year 2005 , there were 17,000 units of houses unsold.

In this context, the private sector involvement becomes an issue because it is well known fact that it main interest is to make lucrative profits. Any cost incurred in producing houses will be transferred to the buyers and the profit margin yielded should be higher than in other sectors (Harvey, 1992). To get the acceptable affordable price of houses or low cost housing, the government was asked to provide more "state land" to housing developers and to expedite the planning approval process (Chan, 1997). Without cheaper premium for land or free land, housing areas were moving out from the urban centers to the fringes mainly by converting the agriculture lands of the private properties. The planning control is, from this point of view, seemed to be more relax. More land released for housing means that planning gives approval to all conversion involving agriculture land. However, this approach does not guarantee the desired effect on house prices because the study in the UK has shown that large acreage of land release for housing development did not favorably change the house prices (Healey, 1992; Bramley, 1993). In addition, housing developers would have embraced more problems in developing agriculture land to be housing estates since the site was outside the local authority boundaries is not covered under any development plan. Even though the site was located within the local authority boundary, it was probably not in the residential zone. This is where the planning constraints exist. 


\section{PLANNING CONTROLS IN HOUSING DEVELOPMENT}

According to the development process, the housing project begins with the land acquisition stage and ends with the selling of houses built. Hence, the planning control comes in at the process of getting statutory approvals (Khairuddin, 2002). Within the development process, the planning constraints only appear when an application for approval is submitted to the local planning authorities or to land offices. In identifying the constraints, it is easier and clearer to discuss them by looking at the housing estate development rather than at the development of a small portion land for housing because housing estates involve large acreage of land area and comprise variety element of land uses.

Housing estates are being developed every where either within the town boundary or its outskirts. Their location, usually, are adjacent to the existing major roads or small towns. Most of the estates are developed after the conversion from agriculture to building category or by filling up the existing mining ponds. The developers would have carried out feasibility study and financial appraisal by which they would be able to gauge the 'yield' of the proposed projects prior the application for planning permission (Simon and Henneberry, 2002). The prospective developer must have adequate capital to proceed with the project. Financial aid can be obtained through bridging-finance facilities with certain interest rates.

The conversion from agriculture to building is under the prerogative of the states where it is delegated to the land offices concerned. In this respect, state town planning offices and the local planning authorities are only asked for recommendations. This requirement is set in the National Land Code 1965 (NLC). Under the NLC, the state may confer a piece of land to an individual or to a company with the specific category attached viz: Agriculture, Building, and Industry. Any change of usage that differs from the said category listed, needs approval from the land offices. According to the Real Estate and Housing Developer Association (REHDA), the time needed for the process of getting approvals from the from the Land Office is highly unpredictable because it comprises of various activities on the part of the government, technical departments such as Tenaga Nasional Bhd., Indah Water Consortium, PUAS and local planning authorities. There were cases where the time taken from the submission up to the approval stage spent more than 2 years (Marbeck, 1997).

The planning office must refer to the development plan of the area before giving consent to the land conversion. The development plan, either Structure Plan or Local Plan if any, identifies the land for housing in the form of new growth areas and attached with development policies that include inter-alia allowable 
densities, plot ratio and provisions for community and amenity facilities. To date, most of town and cities in West Malaysia had their Structure Plans and Local Plans prepared before the amendment of Town and Country Planning Act (TCP) 1976 in 1995. The amendments introduced a new development plan system that comprises National Physical Plan for Peninsular Malaysia (West Malaysia), Structure Plan for the states and Local Plan for town and cities. Consequently, if the land applied was not within the identified area, the planning office would not give approval. So far, the land office has never overruled the planning office for the land conversion approval (Roslan, 2002).

After the land has been converted, the application for the lay out plan approval must be obtained from the local planning authorities. The planning authority may not necessarily be the local authority of the area but can also be the Land Office if the area is not within the local authority boundary (TCP Act, 1976). In considering application for the layout approval, planning offices have many sorts of guidelines and regulations including the planning standards and policies. The application for conversion and housing layout approval does not seem to be easy, as many housing developers face various kinds of obstacles. For example, an applicant must visit or consult about 20 related technical departments which caused considerable delays in getting approval (Chan, 1997). Besides the technical departments involved in the process, the processing of an application also take a very long times to get the planning decision from the state planning office. The client charter printed several categories of applications and the possible period of getting approval. For the layout plan approval, the possible time should be within 12 months but in actual cases there are many more activities involved between the two parties (Planning offices and the applicant) because matters such as the completed forms, fees paid, drawing scale used, information and EIA report attached, and layout design would require more consultation and discussion that directly cause the delays. In addition, in major cities like Kuala Lumpur the number of planning applications to be tabled to the Town Planning Committee per. week are more than 40 whereas the capacity to make a decision is only for between 20 and 30 applications. So, the backlog applications keep on increasing. Thus, the delays in obtaining planning approval seem to be unavoidable during the economic boom period, although that may not be the case during recession.

The Town Planning Committee or the State Planning Authority may impose several conditions or subjects to be included in the proposed layout plan while considering approval based on the relevant development plans or current 'planning materials'. Among the common subjects are the changes of the proposed density, enlargement or relocation of the proposed community facilities as well as the increase in its numbers, infrastructure improvements or 
additional provisions. These requirements and changes may reduce the buildable site for houses; causes the increase in production costs and problems to the developers for whom the requirements and policies outlined by the development plan may force them to reconsider the proposals because the requirement will inevitably increase the production costs (Simon and Henneberry, 2002).

After the lay out approval, especially for a large housing scheme of more than 200 hectares, the applicant may phase out the scheme and consult the land office to submit application for subdivision of land, strata title and for individual titles according to the phase of development and also together with the Requisite Survey Plan (RS plan). The land office may give the approval after undergoing several steps in the process and technical meetings. Hence, this stage does not involve the urban planning office but only the Land Office. The planning office plays its role again when there are applications for planning permission or for 'development order' (for Federal Territory Kuala Lumpur only) according to the phasing of development as determined by the developers. At the development order stage, the consideration for planning matters would be more detailed. The common subjects are traffic circulations, parking requirements, net residential density and net plot ratio for commercial usage, facilities and utilities. In Kuala Lumpur, the development charges for excess density, excess floor area and lack of car-parking provision are calculated at this stage and must be paid before the permission is released. The decisions made by the Planning Authorities almost always contain conditions imposed by the technical departments.

After obtaining the development order and paying the necessary fees, developers must submit application for building approval. The building control section in the local authorities has its own steps of process. While the application is being considered, the developer is allowed to carry out earth work and land leveling for construction. However, this kind of activities requires permission from the Civil Engineering Office (usually Public Work Department). The time taken for building approval which could be more than a year is not going to be discussed in detail here because it does not come under urban planning jurisdiction.

\section{ISSUES OF URBAN PLANNING AND HOUSING DEVELOPMENT}

Planning can impose conditions in giving out approval. The major contribution to the increase in production costs are the provision of infrastructures and changes of the scheme design (Ghani and Choong, 1997). The infrastructure involving high costs includes the identified viaduct, bypassed and the road 
widening. These types of infrastructure construction would have swallowed much of the capital costs leaving a small portion for the others. Moreover, these result in high loan requirements which subsequently increase the amount paid for interest. The amendment to the design does not only refer to the building design, but also the allocation of land for community facilities and amenities according to the specified standards (Planning Standards and Design Guidelines). The developers have to bear all costs and transfer them to the buyers.

By looking at the possible factors in production cost, town planning authority may alter the land availability for housing if the development plan does not identify the land to be new development areas. This is where the anticipated land requirement for a particular town may not accurately reflect the actual acreage of land needed. This technical error, consequently, would cause the potential land and low price land undeveloped (Buang, 1997). The planning officer may also refuse to give recommendation to the land office for converting agriculture land or redeveloping ex-mining ponds. This action, either consciously or unconsciously, will unintentionally be limiting the amount of land to be converted to residential development. Subsequently, land prices will increase because the land approved for housing can be sold at higher prices (Monk, 1991).

Based on the above discussions, it is possible that Town planning may impose constraints to housing development through the development plan by which the land is identified for future development together with development policies on intensity, designs and land use zoning. Through the development control, the local planning authority sets out procedure to be followed, processing requirements, planning standards and duration of its activities. During the decision making, there is more room for town planning to impose extra conditions or amendments and improvement that need to be complied with. The following discussions based on the analysis of the data collected will encompass the dimensions of the constraints.

\section{DATA COLLECTION AND ANALYSIS}

Information about the planning control applied by state and local planning authorities was gathered through the secondary sources such as books and reports, journals and seminar papers relating to housing and planning. The objectives outlined in this paper can be achieved by primary data which were obtained from the housing developers because they were the sector facing the problems. Thus, all housing developers become the 'population' for the sample. 
There were 1099 registered housing developers in Peninsular Malaysia in 2004/2005 (REHDA). Due to unavoidable factors that include limited time, lack of financial resources and manpower, only 137 housing developers were interviewed by using sets of structured questionnaires according to the 'proportionate stratified sample' method. This method of sampling is able to get representatives from each stratum (the registered developers in each state). All registered housing developers in each stratum were given a number each and then the sample was drawn by using the statistic random table. The selected housing developers were then traced to their addresses based on their name of establishments in Real Estate and Housing Developer Association (REHDA) Directory Reports. The size of the sample in this case, however, is adequate for statistical analysis because the size of more than $30(>30)$ is considered as a large sample where the 'mean' will be closer to a 'mean' of normal distributed curve for the whole population so long as the population size is at least twice the sample size (Spiegel, 1972. p 142, McClave and Sincich, 2006).

All completed questionnaires were processed by using the SPSS software that enables the process of factor analysis. This method is able to explain the relationship between the items under study. For the factor analysis, there were several important procedures and steps that needed to be followed (Nachmias, 1996). The method assumes that items representing a single dimension will highly correlate with that dimension. Thus, the correlation between item and factor is represented by a "factor loading". A factor loading is similar to a correlation coefficient that can be interpreted the same way.

\section{DISCUSSION OF FINDINGS}

\section{Results of the data analysis}

The data in Table 1 can be interpreted in many ways. However, for the purpose of the method of identifying the significant constraints of the factors, the coefficient or 'loading' of less than 0.3 can be ignored (Mahzan, 2002). The bold figures show the high factor loading where the relationship between the item and the factors is considered strong. The rest of item loadings are too weak to be considered as good indicators of the dimension investigated. Moreover, the factors with the highest percentage of explained variance provide the most parsimonious representation of the items (Nachmias, 1996.p.472). Therefore, the table reveals that the most parsimonious factor is the development plan (existing Structure and Local Plan) with 66.9 percent and the least parsimonious is planning communication and correspondence ( 3.43 percent) excluding the non planning factors. 
Table 1:

Factors of difficulties in housing development

\begin{tabular}{|l|c|c|c|c|c|c|}
\hline Items & $\mathbf{F ~ 1 ~}$ & $\mathbf{F ~ 2}$ & $\mathbf{F ~ 3}$ & $\mathbf{F ~ 4}$ & $\mathbf{F ~ 5}$ & F 6 \\
\hline Land Location & $\mathbf{0 . 5 8 0}$ & 0.351 & $\mathbf{0 . 4 5 0}$ & 0.383 & 0.210 & 0.216 \\
\hline Land Constraint & 0.276 & 0.165 & $\mathbf{0 . 6 7 3}$ & 0.161 & 0.159 & 0.083 \\
\hline Land Holding & 0.319 & 0.228 & 0.270 & 0.203 & $\mathbf{0 . 6 3 3}$ & 0.127 \\
\hline Land Category & 0.207 & 0.240 & $\mathbf{0 . 5 0 4}$ & 0.212 & 0.249 & 0.166 \\
\hline Land Size & $\mathbf{0 . 4 8 0}$ & 0.192 & $\mathbf{0 . 4 7 9}$ & $\mathbf{0 . 4 2 8}$ & 0.250 & 0.190 \\
\hline Land Conversion & $\mathbf{0 . 6 1 6}$ & 0.316 & 0.302 & 0.316 & 0.363 & 0.169 \\
\hline $\begin{array}{l}\text { Land Subdivision } \\
\text { and individual title }\end{array}$ & $\mathbf{0 . 4 5 5}$ & $\mathbf{0 . 4 9 8}$ & 0.281 & $\mathbf{0 . 4 1 8}$ & 0.251 & 0.120 \\
\hline Layout approval & $\mathbf{0 . 4 5 6}$ & $\mathbf{0 . 4 9 8}$ & 0.281 & $\mathbf{0 . 4 1 8}$ & 0.251 & 0.129 \\
\hline Housing density & $\mathbf{0 . 4 6 2}$ & 0.361 & 0.179 & $\mathbf{0 . 4 4 1}$ & 0.301 & 0.058 \\
\hline Housing design & 0.379 & 0.300 & 0.279 & $\mathbf{0 . 6 7 8}$ & 0.210 & 0.156 \\
\hline Road design & 0.298 & $\mathbf{0 . 6 9 1}$ & 0.162 & 0.188 & 0.176 & 0.097 \\
\hline $\begin{array}{l}\text { Provision of } \\
\begin{array}{l}\text { Community } \\
\text { facilities }\end{array}\end{array}$ & $\mathbf{0 . 7 6 5}$ & 0.278 & 0.276 & 0.205 & 0.236 & 0.137 \\
\hline $\begin{array}{l}\text { Provision of } \\
\text { Utilities }\end{array}$ & 0.393 & $\mathbf{0 . 4 9 5}$ & 0.331 & 0.0 .242 & 0.0 .204 & 0.427 \\
\hline $\begin{array}{l}\text { Open spaces and } \\
\text { recreation }\end{array}$ & $\mathbf{0 . 7 5 2}$ & 0.280 & 0.281 & 0.237 & 0.185 & 0.156 \\
\hline Landscaping & $\mathbf{0 . 4 5 5}$ & 0.388 & 0.304 & 0.299 & 0.281 & $\mathbf{0 . 4 7 3}$ \\
\hline $\begin{array}{l}\text { Percentage of } \\
\text { Variance }\end{array}$ & $\mathbf{6 6 . 9}$ & 5.23 & 5.02 & 3.6 & 3.43 & $\mathbf{2 . 9 7}$ \\
\hline
\end{tabular}

Note: $\mathrm{F}=$ factor loading

Factor 1 represents the difficulties relating to the structure plans and local plan

Factor 2 represents the difficulties relating to the planning standards

Factor 3 represents difficulties relating to procedures in planning applications

Factor 4 represents the difficulties relating to the planning decision,

Factor 5 represents the difficulties relating to the planning communications and correspondents

Factor 6 represents the difficulties relating to non-urban planning roles.

\section{Development Plan (Structure and Local Plan) Factor}

Housing developers are aware of the development plan prepared in the area chosen for their projects because they usually consult their consultants that include town planners and architects. From what Table 1 shows, it is apparent that the policies and concept outlined by the respective development plan are the main cause of difficulties to the developers in developing housing estates. Firstly, regarding the housing land location and the land size, the location chosen for the project must be within the proposed new growth areas. Though 
from the housing developers' point of view, the potential development areas depends upon the economic factors such as the availability of land, low construction costs and demand, their attempts to develop areas other than identified by the development plan become a very risky venture. Those successful housing estates outside the identified growth areas could be considered lucky projects when the location chosen had merits for housing besides those under the special projects providing houses for the hard-core poor group, resettlement schemes and government quarters.

The demand for housing as referred by housing developers is the capability of households to pay for the houses built in that particular area. The sites identified for housing in the development plan to them do not guarantee the housing development will be able to meet the demand. Based on the data obtained from the survey, there were various problems faced by the developers. Housing developers preferred the project site to be close to existing access roads which was an ideal site. The site should also be accessible to the existing infrastructure laid down such as electricity, water supply and sewerage line. Without the existence of basic infrastructure in the area, the housing developers have to face the problems of dealing with the private land owners to erect the necessary infrastructure as required for the development. Therefore, when asked about land preferred for development in such areas, developers/ respondents prefer the road frontage lands to be developed first before they can start looking at the following inner land (second lot from the road side). Developers' experience showed that there were sites suitable for housing development but the access roads had to be erected through private lands. In some cases, the access roads had to be constructed wide enough according to the hierarchy of road - main collector 66 feet wide, leaving the balance of such private land with smaller plot. In such circumstances, the respective land owner refused to negotiate either for sale or for rent and rejected the discussion of possible compensation. This problem usually forces the prospective developers to abandon the project even after obtaining the planning permission.

From what has been highlighted by housing developers, in many circumstances, land dealings have caused interruption to the progress of housing projects. The planning control, especially the conditions imposed related to the accessibility, can not be easily complied with. There is also a similar problem in the case of land use zoning. Although the development plan has shown a housing zone, the land cannot be readily used for housing if the infrastructures have not been laid down by the proper authorities. Besides the new roads needed, there was also a case where the prospective housing developers have to negotiate with the frontage land owners for the sharing provision of community facilities and 
utilities. Therefore, it seems that the land zone for housing has been designated on papers without sorting out land matters at the planning stage.

All these answers lead to the size of land that is large enough to enabling housing developers to get acceptable returns from their investments. When questions asked about how much the profit expected from each development, the answer given shows that the majority of housing developers aim at making $30-50 \%$ profits. Developers' previous experiences are also asked in the survey to obtain the factors that bring about the success of the housing development projects. This means that the previous development were able to help developers to make profits as to be able to sell all houses built to house buyers. The most common factors listed by housing developers were the location of the sites, size of the land, the ownership title, subjects and conditions stated on the titles of the land, the reasonable land price and the ability to obtain planning permission.

With regards to the development plan policies, particularly on housing densities, the interpretation of allowable housing density into net and gross density are subjected to personal opinions and become very confusing. Briefly, it is undeniable that the application of the existing development plans has caused difficulties to many items shown in Table 1 . The developers usually get to know the housing policy indirectly from the rejection of their planning permission in certain areas and reasons outlined by the local planning authority.

\section{Planning Standard Factor}

Planning standards used by local planning authorities are mostly provided by the Federal Town and Country Planning Department Headquarter in Kuala Lumpur. Their application to the site and location outside Kuala Lumpur may have been considered by the planning office concerned. The problems in complying with these planning standards have been highlighted by the housing developers especially in land sub-division and layout plan approval. The problems are related to the quantity and size of community facilities required. The large land acreage required to provide community facilities limits the number of houses that can be built. Moreover, the land used by community facilities must be surrendered free of charge to the government.

Besides the community facilities, the problems also occurred in complying with road designs and road widths. The road design depends on the neighborhood unit to be created and the security measures considered. Less number of out-let to the housing scheme means better security. The requirement to form efficient traffic circulation may defeat the purpose of security measures. The costs of 
land traded of for roads would not always be covered by the revenue through selling the houses based on the market prices. The other problems and difficulties faced by housing developers are the provisions of public utilities such as electrical sub-stations for Tenaga Nasional Berhad and, sewerage treatment plants. The land required to house these utilities is quite large. The quantity and size also depends on the planning standard. The unhappy developers raised the issue of these requirements because utility providers are no longer public authority and are now under the private companies, whereas the planning standards adopted are from the technical department concerned. Without those utilities, the housing scheme concerned could not be implemented.

\section{Procedures for applications}

The submission for an application for planning permission has to be submitted by a registered town planner or any other professionals allowed under their professional Acts. This requirement is however left to the discretion of the local planning authorities. Since the year 2000, most of the local planning authorities in Peninsular Malaysia have adopted this requirement on the belief that professionals like town planners will take into account the effect of the development on the surrounding physical environment. In addition to the above requirement, housing developers have to prepare cumbersome number of plans, accompanied by Proposed Development Reports (PDR) for the planning application. Sometimes the application is rejected because of some technical mistake such as typing error or wrong figures in the technical calculations, but only a small percentage of housing developers have faced this kind of problem. All items required to be furnished on submission for planning application seem to be well understood by housing developers, except several matters such as Quit Rent and Assessment payment receipts. Reasons given by developers are that quit rent receipts are often not held by the agent for the development as it is merely related to administrative purposes. So why does it become a compulsory requirement? The procedure requiring the agent to attach with the adjoining land owner name and address in planning application may cause an additional difficulty to developers because not all landowners are traceable from the Land Office.

Upon receiving an application for planning permission, the local planning authority begins its function by referring it to technical departments or calling for comments. The local planning authority also processes the application by examining the planning standards, assess the report submitted and looking at the zoning and types of density proposed. It also refers to the development plan policies, local issues and local requirements. If the local planning authority 
finds any doubtful data in the applications such as wrong calculation or unacceptable layout design in the proposal, it may ask the developers to come over to the office for discussions. If both parties reached an agreement, the housing developers will take back the drawings and resubmit the application. The majority of housing developers ( 76 percent) complain that sometimes they had to undergo more than three submission exercise because of amendment to an application.

The time taken for processing application starts from the date the application is received by the planning office and it ends when the applicant is informed about 'approve or disapprove' decision obtained after the State Planning Committee (SPC) meeting. Most of the developers' responses show that they have to wait more than 3 years (Mean-3.5 years) for the feedback. What can be learnt from this is that the charter given to the public is not always complied with. There were cases when even more time taken in the processing, depending upon the individual application. Problematic cases may take longer while the more straightforward one may be shorter. The charter advocated in the planning department is meant for the average cases. The longer time taken, as shown in Table 1 depends on many factors; besides the amendment to be made by the applicant, the process also has to take into account the reply from the applicant for each correspondence, time taken for the applicant to resubmit the amendment, the waiting time for the preparation of the concept or lay out plan for the area concerned, waiting for the adoption of the development plan, waiting for the adoption of the new planning standards or guidelines, waiting for the neighbors' objections, if any, and administrative problems such as shortage of man power. The latter refers to the inadequate number of technical and professional staff to handle the application including to do site inspections, to scrutinize the report and to write comments. In some isolated cases, the applicants have to resubmit all the information and plans because the file was lost or could not be traced. Inevitably the applicant has to comply with such request no matter on what the reason is.

\section{Planning Decision Factor}

Approval without 'subject to fulfillment' can only be obtained by an applicant of a small scale housing development such as less than 5 acres sites. Most planning approvals are given with several conditions imposed. The standard condition used by the local planning authority can be anticipated by housing developers. The majority of them said that the conditions to be fulfilled in getting planning permission have been taken into account in the proposed development. If the condition imposed will cause a high increase in construction 
costs, they usually file for appeal. The appeal for the planning permission granted normally takes another 3-6 months (Mean -4.6).

Housing developers complain that some local planning authorities impose unsatisfactory conditions for housing development. They expect the same types of housing development to have similar conditions. However, they find that there are a variety of requirements have to be satisfied with such as size of play ground, road width and number of community facilities. The year to complete a housing project reflects very well the comments given by the housing developers. Matters are made worse when sometimes the decision making process is changing from year to year. The changes may involve the planning standards used, changes in the administration of the local planning authorities and even changes in planning policies.

\section{Non Urban Planning Factors}

There are many subjects highlighted by housing developers shown by Table 1 (Factor Analysis), that do not fall under planning matters although the questions are confined to urban planning. These non planning matters include detailed technical requirements for road constructions, design of utilities and provision, and landscape design. The developers also highlighted that the difficulties in constructing housing could also be due to several other problems commonly related to finance, land matters and economic factors. With regard to finance, housing developers argue that the financial institutions would like to see the experiences and past performance which can hardly be satisfied by new housing developers. This issue which is not really urban planning matters needs no further elaboration. For the land matters, they refer not only to land ownership and tenure, but also the process of acquiring land and transaction dealings. All these matters do cause problems to developers. Multiple land owners and many interested parties involved in a piece of land would make the developers to shy away and choose other land as an alternative. While the urban area becomes larger and larger, there would be less and less big acreage of land with potentially easy land transactions. The potential area for future housing is ultimately located further out of town facing less demand and lack of infrastructures. The applications for land conversion and subdivision will inevitably involve long processes unless the procedure concerned is improved. The implication of a long process would adversely affect the prospect of the proposal because it may make the project non feasible or non viable due to changes in the market environment and sometimes due to increasing material costs. 


\section{CONCLUSION}

There are cases in which the data cannot be elaborated in detail because the developers did not answer the questions fully. Precautions must also be placed in the interpretation of the data because presumably the private sector has its own hidden agenda. The analysis of the data, however, reveals some indication of the factors covered by urban planning affecting housing development. Even though these findings seem to reflect more negative than positive views, it brings to the fore that these important factors must be taken into consideration in forward planning, controlling development and planning decision concerning meeting the housing needs. The dominant factor seems to be associated with the development plan; in other words it becomes the most important guidance in housing land development. Therefore, Town Planners should be more cautious in their decisions, recommendations, and technical analysis in preparing the development plan,

In addition, the development plan needs to be revised after a certain period of time such as every 5 years in order to be in line with the current economic environment. More importantly, these findings highlight new insight to planning control affecting the housing development.

\section{REFERENCES:}

Agus, M.R. 1992. Pembangunan Perumahan: Isu dan Prospek. DBP. Bank Negara Malaysia. 2000. Annual Repor., Bank Negara Malaysia Bank Negara Malaysia. 2001. Annual Report. Bank Negara Malaysia Bank Negara Malaysia. 2005. Annual Report. Bank Negara Malaysia Barlow, James 1993. Controlling the Housing Land Market: Some example from Europe, Urban Studies, Vol. 30, no.7

Bramley, Glen 1993. Planning, the Market and Private House Building, The Planer, January 1993.

Chan, Lawrence 1997. Government Housing Policies and Incentives: the industry viewpoint. In Housing The Nation: A Definitive Study, Kuala Lumpur, CAGAMAS Bhd.

City Hall Kuala Lumpur 1981. Draft Report of Survey: Kuala Lumpur Structure Plan. Dewan Bandaraya Kuala Lumpur.

City Hall Kuala Lumpur 2000. Report of Survey for Reviewing Kuala Lumpur Structure Plan. Dewan Bandaraya Kuala Lumpur and ISI (UTM).

David Adams and Craig Watkins 2002. Greenfields, Brownfields \& Housing Development. Real Estate Issues, Blackwell Publishing 
Ghani Saleh and Choong Lai Chai. 1997. Low cost Housing: Issues and Problem. In Housing The Nation: A Definitive Study. Kuala Lumpur. CAGAMAS.

Ghani Saleh and Lee Lik Meng. 1997. Low Cost Housing in Malaysia. Utusan Publication and Distributor.

Harvey, Jack. 1992. Urban Land Economics. Macmillan

Healey, P. 1991. Model of the development process: a review. Journal of Property Research. Vol. 8, 219-238

Healey, P. 1992. The Reorganization of State and Market in Planning. Urban Studies. Vol. 29. p. 411-434.

Henneberry, J and Rowley S. 2002. Developers' decisions and property market behaviour. In Simon Guy and John Henneberry. eds. Development and Developers: Perspectives on Property. Real Estates Issues, Blackwell Publishing.

Johari, Mohd. Yaakub Hj. 1990. Urban Poverty in Malaysia, Institute for Development Studies (Sabah); Art Printing Works Sdn. Bhd.

Khairuddin Abdul Rashid. 2002. Construction Procurement in Malaysia, International Islamic University Malaysia, Research Centre.

Mahzan, Ahmad Ayob. 1992. Kaedah Penyelidikan Sosio - ekonomi. Dewan Bahasa dan Pustaka.

Malaysia. 1976. Third Malaysia Plan 1976 - 1980. Government Printer; Kuala Lumpur.

Malaysia. 1981. Fourth Malaysia Plan 1981 - 1985. Government Printer; Kuala Lumpur.

Malaysia. 1986. Fifth Malaysia Plan 1986-1990. Government Printer; Kuala Lumpur.

Malaysia. 1991. Sixth Malaysia Plan 1991 -1995. Government Printer; Kuala Lumpur.

Malaysia. 1991. Preliminary Count Report: Population and Housing Census of Malaysia. Department of Statistics Malaysia, Kuala Lumpur.

Malaysia. 1996. Seventh Malaysia Plan 1996 - 2000. Government Printer; Kuala Lumpur.

Malaysia. 2001. Eighth Malaysia Plan 2001 -2005. Government Printer; Kuala Lumpur.

Marbeck, A.B. 1997. Legal and Administrative Framework for Housing: The Private Sector Viewpoint. In Housing The Nation. CAGAMAS BERHAD.

McClave, James $\mathrm{T}$ and Terry Sincich. 2006. Statistics. Pearson Education International

Monk, S. 1991. Land Supply and Housing. Housing Studies. Vol.11

Murie, Alan. 1976. Housing Policy and the Planning System. London, Allen and Unwin

Nachmias, David. 1996. Research Methods in the Social Sciences. Arnold 
Ozay, Mehmet. 1988. Development in Malaysia: Poverty, Wealth and Trusteeship. Ihsan, Kuala Lumpur

Ratcliffe, John. 1974. An Introduction to Town and Country Planning. Hutchinson of London

Roslan Ismail. 2002. Notes for Courses of The Malaysian Institute of Planners, INSTUN (unpublished document).

Simon Guy and John Henneberry Eds. 2002. Development and Developers: Perspectives on Property. Real Estates Issues, Blackwell Publishing.

Spiegel. 1976. Statistic. Schaum Series 